Asian-Australasian Journal of Bioscience and Biotechnology

ISSN 2414-1283 (Print) 2414-6293 (Online)

www.ebupress.com/journal/aajbb

\title{
Review
}

\section{Trends of bivalve (Bivalvia) research in East Malaysia: a systematic review}

\author{
Hadi Hamli and Abdulla-Al-Asif* \\ Department of Animal Science and Fishery, Faculty of Agricultural Science and Forestry, Universiti Putra \\ Malaysia Campus Bintulu, 97008 Bintulu, Sarawak, Malaysia
}

*Corresponding author: Abdulla-Al-Asif, Department of Animal Science and Fishery, Faculty of Agricultural Science and Forestry, Universiti Putra Malaysia Campus Bintulu, 97008 Bintulu, Sarawak, Malaysia. E-mail: jessoreboyhemel@gmail.com

Received: 03 July 2021/Accepted: 25 August 2021/ Published: 31 August 2021

\begin{abstract}
The unique biodiversity in Malaysia makes this country a global hotspot for different aspects of research. Many European and non-native research activities are conducting by different research groups, whereas local institutions also collaborate with them to explore the pristine nature of west (peninsular Malaysia) and East Malaysia (Sarawak and Sabah province). East Malaysia is located in Borneo Island, and the biodiversity of this area are huge. The current review work scrutinized the information about the research activities on aquatic bivalve species and their different aspects of the investigation. This investigation revealed, to date 28 research publications were published on aquatic bivalves from eastern Malaysia, where biodiversity, conservation and ecology was the major aspect of research. The other aspects were aquaculture, natural history and taxonomy, nutritional study, reproduction of bivalve, morphology, and pollution can be mentionable. The major portion of this eastern Malaysia are not investigated and it is assumed that many species are still not reported. Further studies demand to explore the vast bivalve biodiversity of this part of Malaysia.
\end{abstract}

Keywords: Mollusca; Bivalvia; Malaysian Borneo; Sarawak; Sabah

\section{Introduction}

Malaysia is one of the biologically diverse regions on the planet where some fauna have an extremely limited range and are only found in this landmass (Abdullah et al., 2015; Tong, 2020). Eastern part of Malaysia is well known as "Borneo Island", and this huge landmass was formed during the Mesozoic era as a result of the accretion of microcontinental fragments, ophiolite terranes, and Island arc crust onto a Paleozoic continental core (Balaguru et al., 2003). This phenomenon occurred in millions of years ago but it helps to accumulate huge number of unique flora and fauna in this bioregion (Galey et al., 2017; Leonard et al., 2015). The Mollusca fauna were detected unique in nature, especially bivalves; where some of the endemic bivalve species only found in this biogeographic region (Zieritz et al., 2021, 2020).

Although the availability of bivalve fauna are ample in eastern Malaysia, which are reported by several European and local research groups (Ashton et al., 2003; Hamli et al., 2012a; Raven, 2019; Zieritz et al., 2020). The history of bivalve research in eastern Malaysia can be phrased as "one of the oldest" compare to the peninsular Malaysia, as the first taxonomic checklist of bivalve was published in 1981 from peninsular Malaysia; while the first bivalve was reported in Eastern Malaysia through the report of Marcia japonica (J. F. Gmelin 1791) from federal territory of Labuan (Gmelin, 1791) while the first research from the present century was recorded from Sematan mangrove forest, Sarawak (Ashton et al., 2003; Morris and Purchon, 1981; Way and Purchon, 1981). The research of Ashton et al. (Ashton et al., 2003) found the first approach to introduce the bivalve fauna from Malaysian Borneo to the rest of the world; it is assumed that, the major focus of Ashton et al. (Ashton et al., 2003) work was to assess the crustaceans and gastropods macro-fauna in Sematan mangrove forest, but very fortunately they reported three species of bivalve. In the last century a noteworthy work was 
conducted by Turner and Santhakumaran (1989) from Pantai river, Sarawak and its adjacent areas and recorded four endemic bivalve species.

After the initial study, some studies in last decade were also focused on bivalve fauna, targeting heavy metals accumulation by bivalve and biodiversity studies (Abdullah et al., 2007; Shabdin, 2010; Shabdin and Alfred, 2007). The new era of bivalve research in East Malaysia, especially in taxonomic aspect was introduced by Wong and Arshad (Wong and Arshad, 2011), where they reported 18 bivalve species from 12 families from Pulau Mabul, Sabah. The next milestone was settled by Hamli et al. (Hamli et al., 2012a), and they reported 19 species comprising 11 families from different location from Sarawak, Malaysia.

Several gastropod studies were also found from eastern Malaysia including description and identification of Pachychilidae (Hadi Hamli et al., 2020), diversity of Caenogastropoda (H. Hamli et al., 2020a), investigation of edible gastropod (Hamli et al., 2013), etc. However, the present focus was only penetrated into the bivalves and research aspects of bivalves in Sarawak and Sabah.

It is evident that only few academic and research institutions were found involved in the bivalve research in east Malaysia; where the major portion were contributed by Universiti Putra Malaysia, Bintulu Sarawak campus (13 papers as first author). The other academic institutions such as Universiti Malaysia Sarawak also conducted several studies.

The good news is that Eastern Malaysia is abundant in undiscovered and unreported bivalve species; the bad news is that the number of researchers and published documents on various aspects of bivalve fauna were found limited. Considering these potentiality and gaps in research this review aims to compile and analyze various aspects of bivalve research conducted in East Malaysia. This review also provide a glimpses of existing research facilities available in Eastern Malaysia to conduct bivalve research and the institutional framework to support research.

\section{Literature search strategy}

The distribution and abundance records of bivalves in Eastern Malaysia (Sarawak and Sabah) (Figure 1) were accumulated from the existing literature, monographs, reviews, checklists, catalogues, poster, conference paper, conference poster, websites and fishery reports from East Malaysian water from the time periods of 1791 to 2021. The literature search were performed with Google Scholar web search using "Publish or Perish" software (Harzing, 2007) from the time period of March 2019 and September, 2021. The specific key words were inserted and search for the documents [("Malaysia" AND "Borneo") AND ("Bivalvia" OR "Bivalve" OR "Sarawak" OR "Sabah" OR "Marine Bivalve" OR "Freshwater Bivalve" OR "Macrofauna" OR "Marine Mussel" OR "Freshwater Mussel" OR "Mollusk" OR "Freshwater Snails" OR "Marine Snails" "Freshwater Clam" OR "Marine Clam" OR "Macrofauna"]. We extracted the papers related with aquatic Bivalvia in Eastern Malaysia. After extraction of all related published papers we classified the papers into seven research niche, including (a) biodiversity, ecology and conservation, (b) aquaculture, (c) natural history and taxonomy, (d) nutrition, (e) reproduction, (f) morphology, and (g) pollution study.

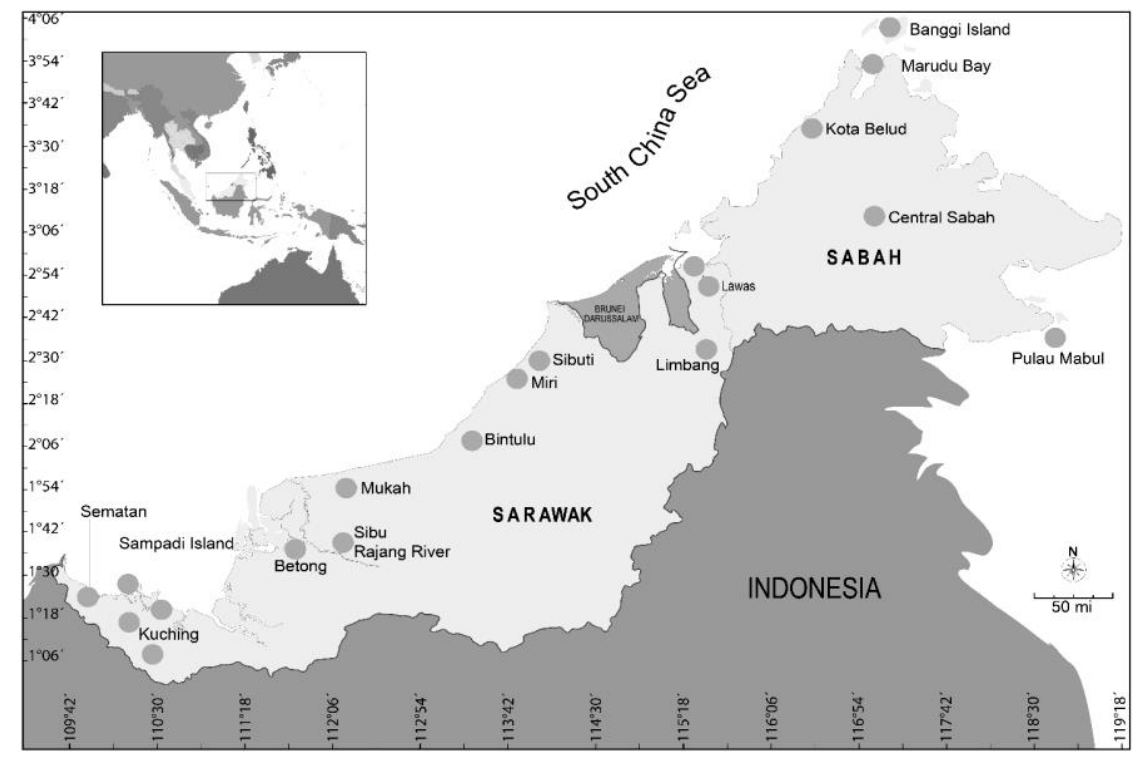

Figure 1. Map showing the places of bivalve research conducted in east Malaysia. 
3. Bivalves research aspects

\subsection{Biodiversity, ecology and conservation}

Biodiversity assessment was found one of the major window (57\%) in bivalve research in east Malaysia (Figure 4). A total 16 published documents were detected where major portion of the reported bivalve species through this research aspect. The first bivalve biodiversity in eastern Malaysia was reported by Turner and Santhakumaran (1989) from Pantai river, Sarawak; while the next report was tracked in 2003 from Semantan mangrove forest, Sarawak (Ashton et al., 2003).

However, a very recent published document from Lawas seagrass beds, Sarawak recorded 18 species of bivalve (Al-Asif et al., 2020). The major biodiversity checklist was reported from all over the Sarawak revealed 19 species of bivalves (11 families) in 2012 (Hamli et al., 2012a) (Table 1). However, from Pulau Mabul, Sabah 18 species of bivalve (12 families) were also reported (Wong and Arshad, 2011). The work of Al-Asif et al. (2020), Hamli et al. (2012a) and Wong and Arshad (2011) were completely reported marine or brackish habitat's bivalve species; whereas, Zieritz et al. (2020) reported six species of bivalve, Zieritz and Lopes-Lima (2018) reported eight freshwater bivalve species from family Unionidae, over the eastern Malaysia. Most of the biodiversity related published documents were site specific or species/family specific; while the study of Zieritz et al. (2020), Raven (2019), Hamli et al. (2012b), and Hamli et al. (2012a) covers major area of eastern Malaysia; especially Hamli et al. (2012b) and Hamli et al. (2012a) considered the whole Sarawak during sampling.

The study of Al-Asif et al. (2021) recorded 76 freshwater, brackish and marine water bivalve species from Malaysian Borneo from 12 orders, 18 superfamilies and 27 families; which was the first complete and comprehensive review of bivalve biodiversity and conservation research from Malaysian Borneo. The study of Al-Asif et al. (2021) also suggested some conservation aspects of bivalve fauna from Malaysian Borneo which might be helpful to protect and in some cases introduce of bivalve fauna to its natural ecosystem in East Malaysia.

The study of Zieritz et al. (2021) reported a completely new freshwater genus, Khairuloconcha from Eastern Malaysia having two new species, namely, Khairuloconcha sahanae (Zieritz et al. 2021) and Khairuloconcha lunbawangorum (Zieritz et al. 2021). The study also compared the genetic material with the other species of Unionida which suggested that these species are native to the eastern Malaysia. They suggested the habitat protection, reintroduction of species, captive breeding and legislative framework might helpful to support the sustainability of these newly recorded species.

On the other hand, ecological and biodiversity study of Zakirah et al. (2019) from Buntal Bay, Sarawak recorded Tellina sp. with some polycheata species. The bivalve biodiversity in major area of Sarawak and Sabah remains still undiscovered and not reported. Most of the research were conducted from eastern Malaysia at the sites where vehicles and transportations might access; the major part in deep forest and creek areas are still not investigated. This circumstance can be considered as the one of the gap for bivalve research.

\subsection{Aquaculture}

This review finds only one aquaculture related study of Hamli et al. (2020b), and the research team was in a hunt for a potential phytoplankton candidate for live Sinanodonta woodiana bivalve aquaculture. The result of the study found some of the phytoplankton for instance, Selenastrum sp., Licmophora sp. and Gloeocapsa sp. isolated from native pond showed best result during phytoplankton culture and the study recommended to use of these phytoplankton for bivalve aquaculture, as bivalves are phytoplankton feeder. In a recent publication Hamli et al. (2019) discussed the potentiality of local bivalve as the potential candidate of aquaculture. It is assumed that, this wing of bivalve research is going to expand in the east Malaysia in next few decades.

\subsection{Natural history and taxonomy}

The first report of bivalve species was declared by the research of Gmelin (1791) from federal territory of Labuan (a small island near Sarawak coast and Malaysian Borneo) with the report of Marcia japonica (J. F. Gmelin 1791) (reported as Venus japonica Gmelin, 1791). While with in next one hundred years there were no bivalve study was tracked in Malaysian Borneo, and in 1909 Sowerby (1909) reported Pelecyora exilium (G. B. Sowerby III, 1909) (reported as Dosinia exilium) from the coast of Sarawak.

The publication of Raven (2019) supports some of the animal dispersal theories presumed previously that some Mollusca species (reported five bivalve species in total) move and settled one place to another in the north-west Borneo. He argued that, nipa rafts (Nypa fruticans) might be one of the possible transportation material during the Cenozoic periods. The dispersal and transportation history of animals are different from bivalve; as these creatures are slow mover and they can spend their whole life where they born. The study of Raven (2019) 
provided evidence that, bivalve species for example, Neotrapezium sublaevigatum from family Trapezidae, Magallana rivularis from family Ostreidae might live on the leaf of nipa tree and use it as the dispersal medium from one place to another.

\subsection{Nutrition}

The present review found nutritional study of Meretrix lyrata bivalve was solely based on the organ specific mineral contents (Idris et al., 2017a). The study revealed that, minerals such as, $\mathrm{Na}$ and $\mathrm{Fe}$ found in high concentration in the tissues compared to other minerals. The result of Idris et al. (2017a) supports that, being a marine or brackish habitat species $M$. lyrata accumulate the elements $\mathrm{Na}$ and $\mathrm{Fe}$ in high amount and stores them in their tissue. From this study, it is also revealed that, bivalves can be used as the highly nutritional food items.

\subsection{Reproduction}

The first reproductive study on bivalve reproduction cycle was conducted by Hamli et al. (2015a); they revealed that, histological analysis might be helpful for sex identification of Meretrix lyrata; while some of report suggested that the gender identification of $M$. lyrata found almost near to impossible (Camacho-Mondragón et al., 2012). However, the study of Hamli et al. (2015a) provided the first insight of the maturation, spawning stage and season of the species in eastern Malaysia. Which might opened a window for the wild bivalve collectors and policy making organization to impose ban on the particular time of the year.

The investigation of Hamli et al. (2017) introduced condition index (CI) to measure, either the female bivalve $M$. lyrata individual is ready to spawn or not. The high CI referred, comparatively high body weight, and the individual is close to maturity stage and early spawning stage, which found directly connected with the breeding seasons. This study also establish relations between the CI and water quality parameters especially ammonia nitrogen might be the influential factors with the condition index. Its due to M. lyrata is a benthic animal and decomposition materials might harmful for the growth and maturity of this species. In another reproductive investigation revealed that gonadal development of Polymesoda expansa and generate information on spawning and breeding season of the bivalve species (Idris et al., 2017b).

\subsection{Morphology}

Morphometric keys were used by Hamli et al. (2015b) in different shell parameters to identify and differentiate three mangrove calm species namely, Polymesda erosa, $P$. bengalensis and P. expansa from family Corbiculidae. The evidence and statistical analysis proved that, features for instance, standard length, ligament length, ventral posterior margin length, etc. were the key identification parameters to separate these three species.

The other study of Hamli et al. (2016) investigated inner shell features of mangrove clam Meretrix lyrata, $M$. meretrix and $M$. lusoria and revealed that, the proportional ration standard length for shell wide, ligament length, anterior length, length of cardinal tooth, adductor scar width scar, posterior adductor scar width scar, and pallial sinus open scar might be the main morphological features to differentiate these Meretrix sp. from Sarawak.

A recent study of Idris et al. (2021) revealed 20 bivalve species from 12 families, while suggested ventral posterior margin length/ distance from the anterior margin to posterior margin and the length from anterior cardinal tooth to posterior cardinal tooth/ distance from the anterior margin to posterior margin features might be helpful to identification and differentiate between Geloina species.

\subsection{Pollution}

So far, one investigation was conducted to assess the impact of heavy metal such as, $\mathrm{Cd}, \mathrm{Cu}, \mathrm{Cr}, \mathrm{Pb}$ and $\mathrm{Zn}$ on Meretrix meretrix in two different estuaries in Sabah (Abdullah et al., 2007). This study suggested that, human intervened estuary with high industrial effluent disposal might force M. meretrix to accumulate the toxic heavy metals, in their tissue. This study was an eye opening findings in Malaysian estuary; and the study might helpful to assess the pollution in Malaysian estuary, where bivalve can be used as bio indicator (Table 1). 
Table 1. Research aspects on bivalve in eastern Malaysia.

\begin{tabular}{|c|c|c|c|c|c|c|}
\hline Year & Habitat & Location & $\begin{array}{l}\text { Number of species } \\
\text { reported }\end{array}$ & $\begin{array}{l}\text { Number of } \\
\text { family }\end{array}$ & Research Aspect & Sources \\
\hline 2021 & Marine and Fresh water & Malaysian Borneo & 76 & 27 & $\begin{array}{l}\text { Biodiversity and } \\
\text { conservation }\end{array}$ & Al-Asif et al. (2021) \\
\hline 2021 & Freshwater & Borneo (Sarawak and Sabah) & 5 & 1 & $\begin{array}{l}\text { Biodiversity, } \\
\text { Multidimensional }\end{array}$ & Zieritz et al. (2021) \\
\hline 2021 & $\begin{array}{l}\text { Marine, Brackish and Fresh } \\
\text { water }\end{array}$ & Sarawak & 21 & 12 & Morphology & Idris et al. (2021) \\
\hline 2020 & Marine & Lawas, Sarawak & 18 & 9 & Biodiversity & Al-Asif et al. (2020) \\
\hline 2020 & Freshwater & UPM Bintulu, Sarawak & 1 & 1 & Aquaculture & Hamli et al. (2020b) \\
\hline 2020 & Freshwater & $\begin{array}{l}\text { East Malaysia } \\
\text { Sarawak) }\end{array}$ & 6 & 1 & Biodiversity & Zieritz et al. (2020) \\
\hline 2019 & Marine & Buntal Bay, Sarawak & 1 & 1 & Ecology & Zakirah et al. (2019) \\
\hline 2019 & Brackish & North-West Borneo, Sarawak & 5 & 4 & Natural History & Raven, (2019) \\
\hline 2018 & Freshwater & $\begin{array}{l}\text { East Malaysia } \\
\text { Sarawak) }\end{array}$ & 8 & 1 & Biodiversity & $\begin{array}{l}\text { Zieritz and Lopes-Lima, } \\
(2018)\end{array}$ \\
\hline 2017 & Marine & Kuching, Sarawak & 1 & 1 & Reproduction & Hamli et al. (2017) \\
\hline 2017 & Marine & Kuching, Sarawak & 1 & 1 & Nutrition & Idris et al. (2017a) \\
\hline 2017 & Marine & Miri, Sarawak & 1 & 1 & Reproduction & Idris et al. (2017b) \\
\hline 2017 & Marine & Marudu Bay, Sabah & 7 & 6 & Biodiversity & Matsumoto et al. (2017) \\
\hline 2016 & Brackish & Miri, Sarawak & 2 & 2 & Biodiversity & Abu Hena et al. (2016) \\
\hline 2016 & Marine & Kuching, Sarawak & 3 & 1 & Morphology & Hamli et al. (2016) \\
\hline 2015 & Marine & Over Sarawak & 3 & 1 & Morphology & Hamli et al. (2015b) \\
\hline 2015 & Marine & Kuching, Sarawak & 1 & 1 & Reproduction & Hamli et al. (2015a) \\
\hline 2014 & Marine & Kuching, Sarawak & 5 & 3 & Biodiversity & Shabdin et al. (2014) \\
\hline 2012 & Marine and Fresh water & Over Sarawak & 14 & 8 & Biodiversity & Hamli et al. (2012b) \\
\hline 2012 & Marine and Fresh water & Over Sarawak & 19 & 11 & Biodiversity & Hamli et al. (2012a) \\
\hline 2011 & Marine & Sabah & 18 & 12 & Biodiversity & Wong and Arshad (2011) \\
\hline 2010 & Brackish & Rajang River, Sarawak & 3 & 3 & Biodiversity & Shabdin (2010) \\
\hline 2007 & Marine and Fresh water & Sarawak & 4 & 3 & Biodiversity & Shabdin and Alfred ( 2007) \\
\hline 2007 & Marine & Sabah & 1 & 1 & Pollution & Abdullah et al. (2007) \\
\hline 2003 & Marine & Kuching, Sarawak & 3 & 3 & Biodiversity & Ashton et al. (2003) \\
\hline 1989 & $\begin{array}{l}\text { Marine, Brackish and Fresh } \\
\text { water }\end{array}$ & Pantai river, Sarawak & 6 & 1 & Biodiversity & $\begin{array}{l}\text { Turner and Santhakumaran } \\
\text { (1989) }\end{array}$ \\
\hline 1909 & Marine & Sarawak & 1 & 1 & Natural History & Sowerby (1909) \\
\hline 1791 & Marine & Federal Territory of Labuan & 1 & 1 & Natural History & Gmelin (1791) \\
\hline
\end{tabular}




\section{Research trends}

The extracted data analysis from publish or perish software revealed that, the first study on bivalve research in this century was conducted in eastern Malaysia in 1989 from Pantai river, Sarawak (Turner and Santhakumaran, 1989) and Semantan mangrove forest, Sarawak (Ashton et al., 2003). While the first record was tracked back in 1791 by the report of Marcia japonica (J. F. Gmelin 1791) Gmelin, (1791). With a gap of three years the second research was published in 2007 (Abdullah et al., 2007; Shabdin and Alfred, 2007). It was also observed that, since 2014, the bivalve research related publications were very frequent. The trend analysis revealed that, number of publications are increasing now a days (Figure 2).

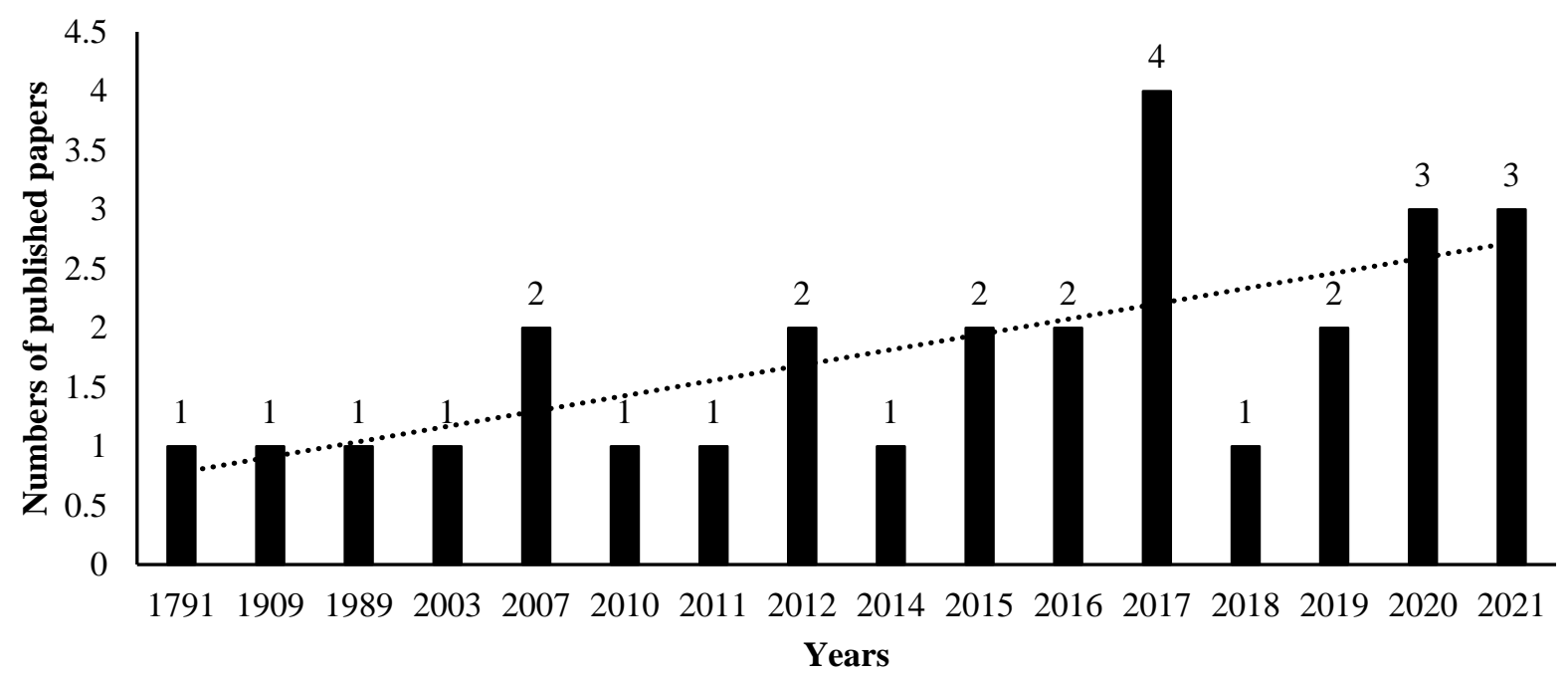

Figure 2. Year wise available published documents on bivalve fauna in Eastern Malaysia.

The available publications were checked with Scopus database and found 54\% (15 documents) of the documents were indexed in the Scopus database; where as 46\% (13 documents) of the documents were not indexed in Scopus database (Figure 3). The analysis also suggested that, most of recent year publications were indexed in Scopus database, which referring the number of good quality publications and researchers are increasing in this fields. It is also mentionable here that, the publication of the non-Scopus indexed journals are local but peer reviewed, so the quality of the publications rather not to be questioned. It was found two report materials (Matsumoto et al., 2017; Zieritz and Lopes-Lima, 2018) published by Universiti Malaysia Sabah (UMS) and International Union for Conservation of Nature (IUCN), whereas one conference material (poster) (Abu Hena et al., 2016) was included in the present review, from International Biology Symposium 2016, organized by Universiti Putra Malaysia. Although these three documents were not indexed in Scopus but they were approved by either Universiti experts, IUCN expert groups or conference authority.

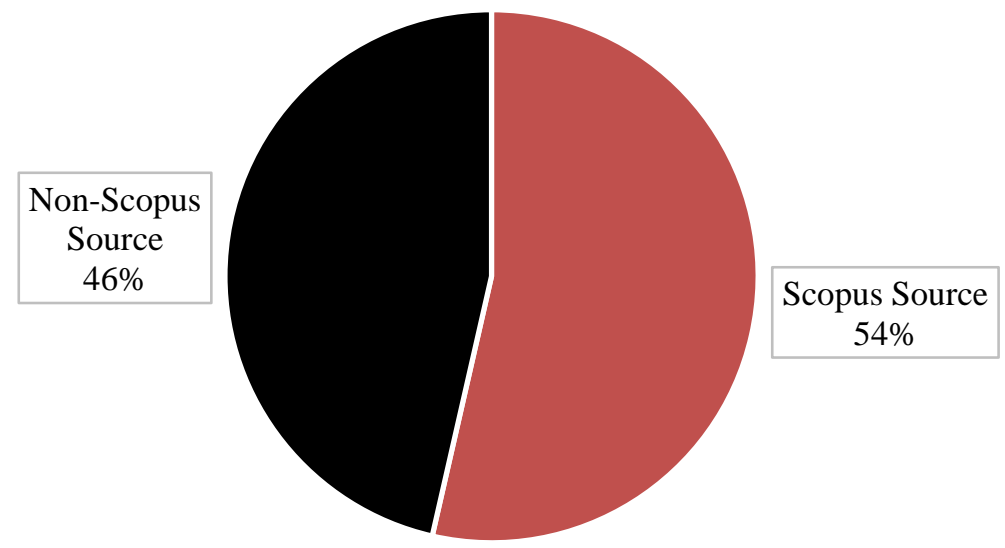

Figure 3. Sources of available published documents on bivalve fauna in Eastern Malaysia. 
Biodiversity was the highest (57\%; 16 documents) aspects on bivalve research available in eastern Malaysia , followed by reproduction aspect, morphology and natural history and taxonomy (11\%; 3 documents each), and rest of the aspects found less than 5\% (1 document), including aquaculture, natural history and taxonomy, nutrition, morphology, and pollution (Figure 4).

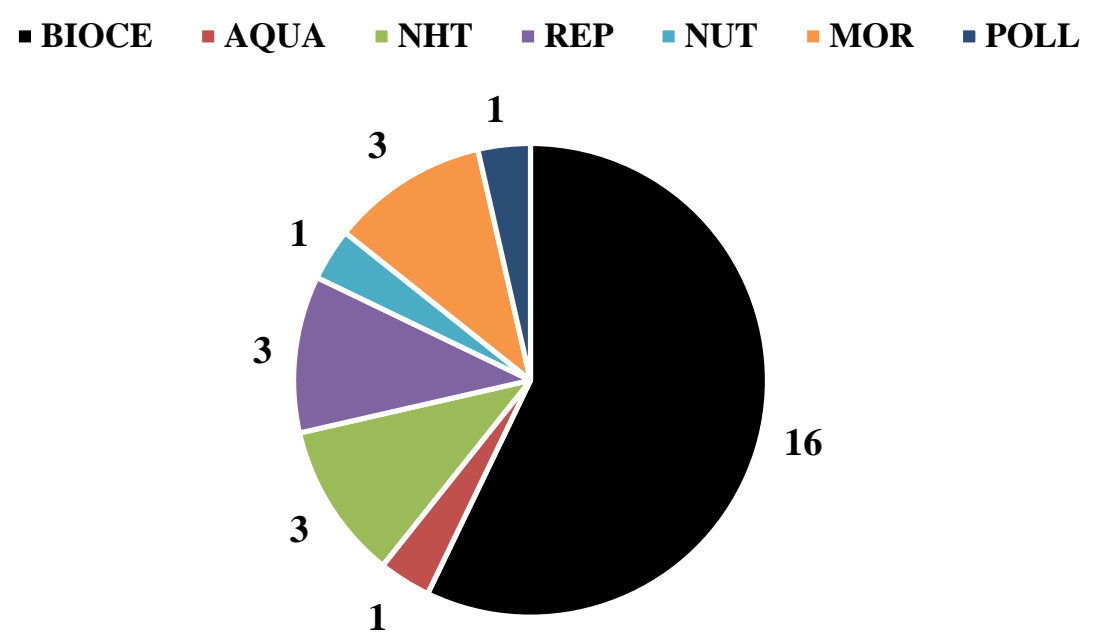

Figure 4. Research aspects on bivalve fauna in Eastern Malaysia (BIOCE=Biodiversity, conservation and ecology; AQUA = Aquaculture; NHT $=$ Natural History and Taxonomy $;$ REP $=$ Reproduction; NUT $=$ Nutrition; MOR= Morphology; and POLL=Pollution).

The trend analysis of previously accumulated data indicated that, if current research trends continue, a significant increase in research publication will occur in the year 2031 (exponential growth), and the number of publications will continue to grow rapidly thereafter, possibly exceeding previous decades' levels (Figure 5). It is always hoped, however, that the number of publications will increase in the coming decades. The current decade demonstrates a rapid exponential growth. Therefore, more academic involvement including existing universities in east Malaysia will definitely increase the number of research documents and aspects on bivalve research.

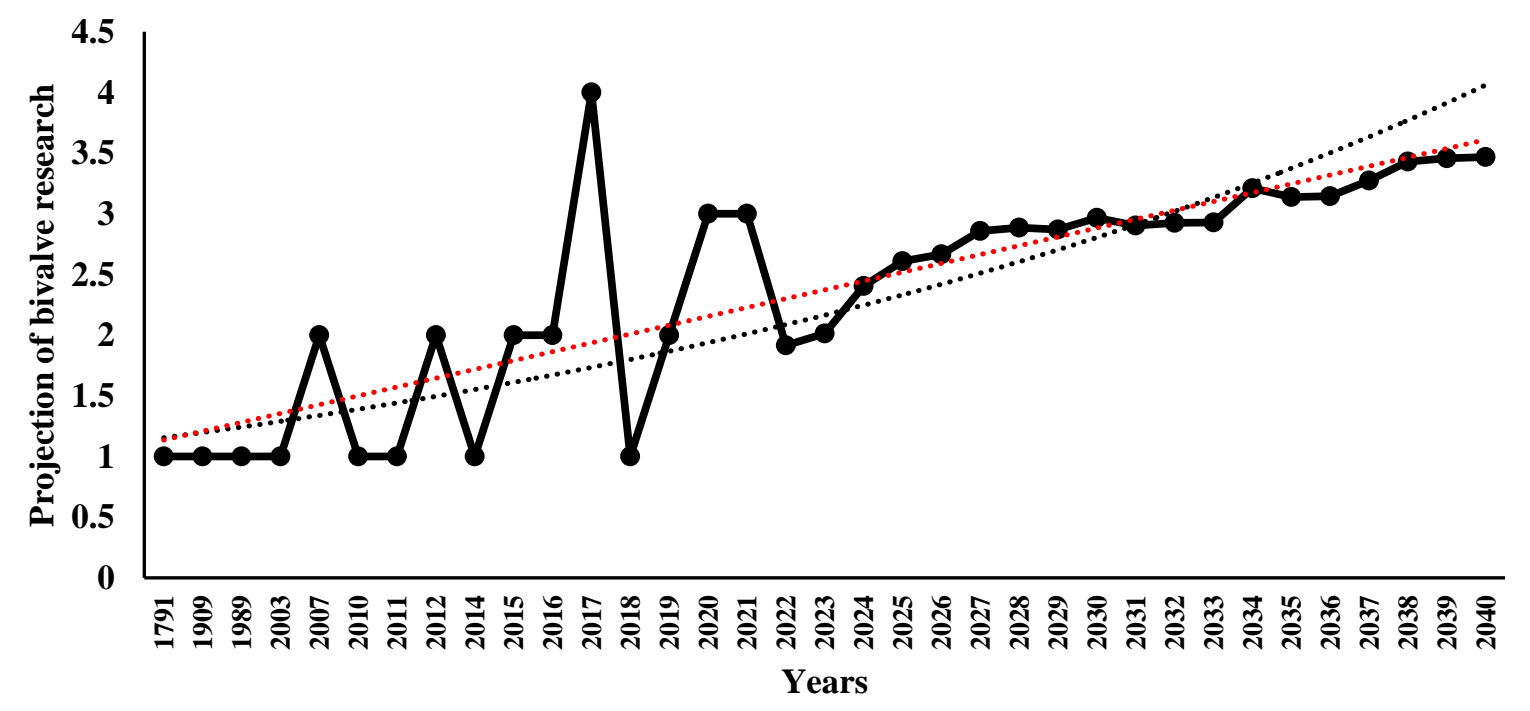

Figure 5. Projections of bivalve research using currently available data and publications (linear vs. exponential growth). 
The first authorship of a published document is significant, and the majority of available published documents were first authored at Universiti Putra Malaysia Bintulu Campus (UPMKB) (46\%; 13 documents), followed by Universiti Malaysia Sarawak (UNIMAS) (14\%; 4 documents), and Universiti Malaysia Sabah (UMS), University of Nottingham (UN) and Others (OT) (7\%; 2 documents); while the remaining affiliated first authors contributed $4 \%$ each (1 documents) (Figure 6).

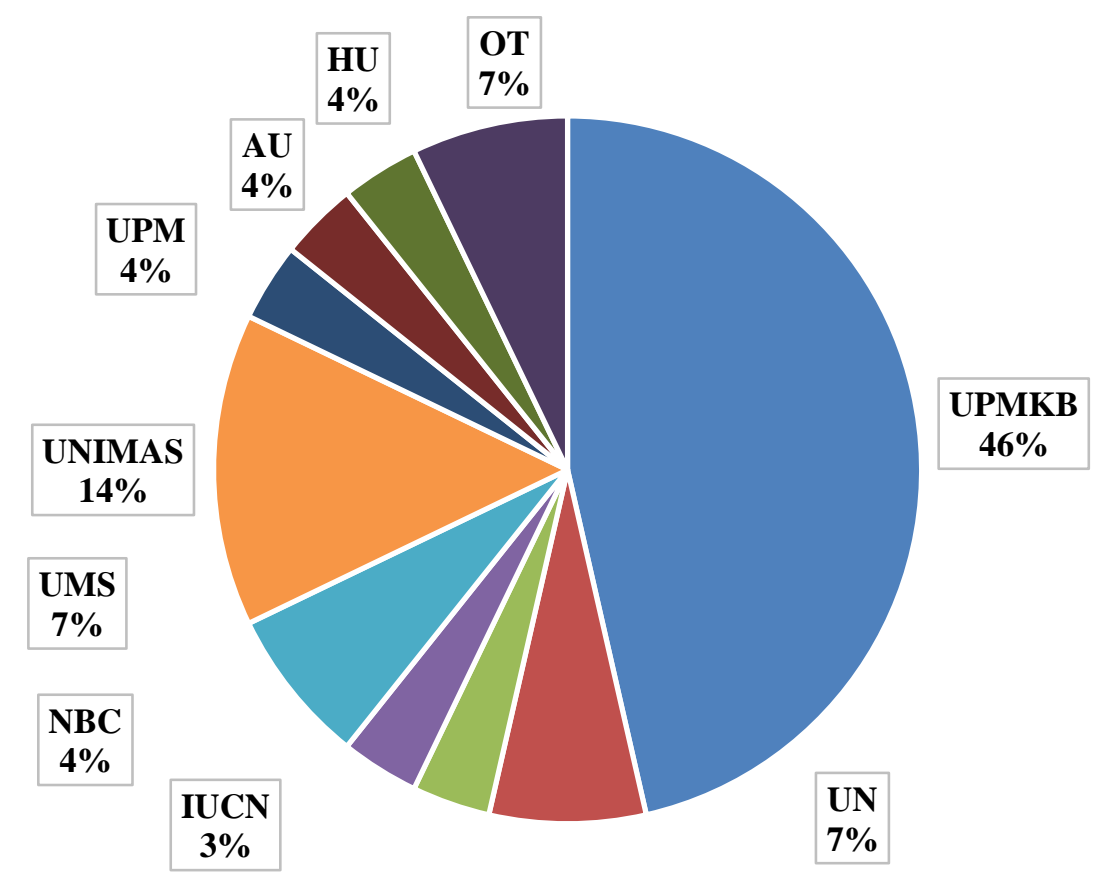

Figure 6. Number of published documents based on institutions of first author. (UPMKB= Universiti Putra Malaysia Bintulu Campus; UN= University of Nottingham; IUCN= International Union for Conservation of Nature; $\mathbf{N B C}=$ Naturalis Biodiversity Center; UMS= Universiti Malaysia Sabah; UNIMAS= Universiti Malaysia Sarawak; UPM= Universiti Putra Malaysia, Serdang; $\mathbf{A U}=$ Aarhus University; HU=Harvard University; OT=Others).

\section{Conclusions}

The trends and different aspects of bivalve research are discussed throughout the review. The findings and discussions of the current review will give a quick insight of 230 years of bivalve research in eastern Malaysia. The present investigation also discussed the future trends of publication in upcoming two decades. The number of the bivalve research and aspects are increasing in eastern Malaysia, which can be considered as the positive changes in the different stakeholders.

\section{Acknowledgements}

The research team would like to acknowledge the Ministry of Higher Education Malaysia FRGS research grant code, FRGS/1/2018/WAB13/UPM/02/2 and department of Animal Science and Fishery, Universiti Putra Malaysia Bintulu Sarawak campus for the facilities and supports during the study.

\section{Conflicts of interest}

None to declare.

\section{Authors' contribution}

Conceptualization: Abdulla-Al-Asif and Hadi Hamli; methodology: Abdulla-Al-Asif; data collection: AbdullaAl-Asif; validation: Abdulla-Al-Asif; data curation: Abdulla-Al-Asif; statistics and presentation: Abdulla-AlAsif; writing - original draft preparation: Abdulla-Al-Asif and Hadi Hamli; writing - review and editing: Abdulla-Al-Asif and Hadi Hamli; visualization, Abdulla-Al-Asif; supervision: Hadi Hamli; project administration: Abdulla-Al-Asif and Hadi Hamli; funding acquisition: Hadi Hamli, all authors have read and agreed to the published version of the manuscript. 


\section{References}

Abdullah M, MP Mamat, MR Yaacob, A Radam and LH Fui, 2015. Estimate the conservation value of biodiversity in national heritage site: A case of Forest Research Institute Malaysia. Procedia Environ. Sci., 30: $180-185$.

Abdullah MH, J Sidi and AZ Aris, 2007. Heavy metals (Cd, Cu, Cr, $\mathrm{Pb}$ and $\mathrm{Zn})$ in Meretrix meretrix Roding, water and sediments from estuaries in Sabah, North Borneo. Int. J. Environ. Sci. Educ., 2: 69-74.

Abu Hena MK, MH Idris, RMY Khairul, MKA Bhuiyan, N Hoque and U Kumar, 2016. Diversity of macrobenthos in the mangrove forest of Kuala Sibuti, Miri, Sarawak., In: Malaysia International Biology Symposium (i-SIMBIOMAS 2016). Malaysia International Biology Symposium, Putrajaya International Convention Center, Putrajaya, Malaysia, pp. 1-2.

Al-Asif A, H Hamli, Abu MK Hena, MH Idris, GJ Gerusu, JB Ismail and NU Karim, 2020. Benthic macrofaunal assemblage in seagrass-mangrove complex and adjacent ecosystems of Punang-Sari Estuary, Lawas, Sarawak, Malaysia. Biodiversitas, 21: 4606-4615.

Al-Asif A, H Hamli, MK Abu Hena, MH Idris, GJ Gerusu, J Ismail and MH Abualreesh, 2021. Bivalves (Bivalvia) in Malaysian Borneo: status and threats. J. Threat. Taxa, 13: 19553-19565.

Ashton EC, DJ Macintosh and PJ Hogarth, 2003. A baseline study of the diversity and community ecology of crab and molluscan macrofauna in the Sematan mangrove forest, Sarawak, Malaysia. J. Trop. Ecol., 19: 127142.

Balaguru A, G Nichols and R Hall, 2003. The origin of the "circular basins" of Sabah, Malaysia. Bull. Geol. Soc. Malaysia, 46: 335-351.

Camacho-Mondragón MA, M Arellano-MartíNez and BP Ceballos-VáZquez, 2012. Particular features of gonadal maturation and size at first maturity in Atrina maura (Bivalvia: Pinnidae). Sci. Mar., 76: 539-548.

Galey ML, A van der Ent, MCM Iqbal and N Rajakaruna, 2017. Ultramafic geoecology of South and Southeast Asia. Bot. Stud., 58: 1-28.

Gmelin JF, 1791. Caroli a Linnaei Systema Naturae per Regna Tria Naturae, in: Gmelin JF (Ed.), Vermes. G.E. Beer, Lipsiae, Leipzig, pp. 3021-3910.

Hamli H, SHS Azmai, SA Hamed and A Al-Asif, 2020a. Diversity and habitat characteristics of local freshwater Gastropoda (Caenogastropoda) from Sarawak, Malaysia. Singapore J. Sci. Res., 10: 23-27.

Hamli H, NA Hamed, SHS Azmai and MH Idris, 2020. Conchology variations in species identification of Pachychilidae (Mollusca, gastropoda, cerithiodea) through multivariate analysis. Trop. Life Sci. Res., 31: $145-158$.

Hamli H, N Hashim and A Al-Asif, 2020b. Isolation and potential culture of phytoplankton live feed for freshwater mussels Sinanodonta woodiana (Lea, 1834). Asian J. Anim. Sci., 14: 127-136.

Hamli H, MH Idris, MK Abu Hena and AH Rajaee, 2019. Fisheries assessment, gametogenesis and culture practice of local bivalve: A review. Pertanika J. Trop. Agric. Sci., 42: 103-124.

Hamli H, MH Idris, MK Abu Hena, AH Rajaee and A Arshad, 2016. Inner shell as variation key of local hard clam Meretrix spp. J. Environ. Biol., 37: 641-646.

Hamli H, MH Idris, MK Abu Hena and SK Wong, 2012a. Taxonomic study of edible bivalve from selected division of Sarawak, Malaysia. Int. J. Zool. Res., 8: 52-58.

Hamli H, MH Idris, MK Abu Hena and SK Wong, 2012b. Diversity of edible mollusc (Gastropoda and Bivalvia) at selected divison of Sarawak, Malaysia. Int. J. Adv. Sci. Eng. Inf. Technol., 2: 5-7.

Hamli H, MH Idris, MK Abu Hena, SK Wong and A Arshad, 2013. Checklist and habitat descriptions of edible gastropods from Sarawak, Malaysia. J. Fish. Aquat. Sci., 8: 412-418.

Hamli H, MH Idris, AH Rajaee and MK Abu Hena, 2015a. Reproductive cycle of hard clam, Meretrix lyrata Sowerby, 1851 (Bivalvia: Veneridae) from Sarawak, Malaysia. Trop. Life Sci. Res., 26, 59-72.

Hamli H, MH Idris, AH Rajaee, MK Abu Hena and MN Hoque, 2017. Condition index of Meretrix lyrata (Sowerby 1851) and its relationship with water parameter in Sarawak. Sains Malaysiana, 46: 545-551.

Hamli H, AA Rahim, MH Idris, MK Abu Hena and WS King, 2015b. Morphometric variation among three local mangrove clam species of Corbiculidae. Songklanakarin J. Sci. Technol., 37: 15-20.

Harzing A, 2007. Publish or Perish. Available at: https://harzing.com/resources/publish-or-perish.

Idris MH, H Hamli, MK Abu Hena, RA Lah and NMSN Jaafar, 2021. Study of diversity and morphometry in edible bivalves and gastropods from a coastal wetland in Sarawak. Songklanakarin J. Sci. Technol., 43: 889896.

Idris MH, H Hamli, MK Abu Hena and AH Rajaee, 2017a. Distribution of mineral contents in the selected tissues of Meretrix lyrata. J. Fish. Aquat. Sci., 12: 149-156.

Idris MH, AA Rahim, H Hamli, MH Nesarul and MK Abu Hena, 2017b. Determination of gonad development 
of mangrove clam Polymesoda expansa (Mousson 1849) by histological classification. J. Fish. Aquat. Sci., 12: $168-176$.

Leonard JA, RJ den Tex, MTR Hawkins, V Muñoz-Fuentes, R Thorington and JE Maldonado, 2015. Phylogeography of vertebrates on the Sunda Shelf: A multi-species comparison. J. Biogeogr., 42: 871-879.

Matsumoto MB, E Saleh, Z Waheed, S Muhammad Ali and J Madin, 2017. Marine profiling of Marudu Bay, Sabah, Malaysia: Final Report. Sabah. pp. 1-88.

Morris S and RD Purchon, 1981. The marine shelled Mollusca of west Malaysia and Singapore Part 3, Bivalvia. J. Molluscan Stud., 47: 322-327.

Raven JGMH, 2019. Notes on molluscs from NW Borneo - Dispersal of molluscs through nipa rafts. The Festivus, 51: 3-10.

Shabdin ML, 2010. Macrofauna of Rajang River, Sarawak, Malaysian Borneo. J. Trop. Biol. Conserv., 7: 1130.

Shabdin ML and A Alfred, 2007. Commercial Molluscs distribution of the Western Part of Sarawak. Sarawak Museum J., 63: 167-178.

Shabdin ML, A Azizil, F Abg, S Atiqah and A Rahim, 2014. Marine gastropod and bivalves of Sampadi Island, Lundu, Sarawak, In: Proceedings of Aquatic Science Colloquium on Pulau Sampadi Marine Life Expedition. Department of Aquatic Science, Faculty of Resource Science and Technology, Universiti Malaysia Sarawak, Sarawak, pp. 75-87.

Sowerby GBI, 1909. Descriptions of new species of Terebra, Pleurotoma, Trochus, Tellina, Dosina, and Modiola. Proc. Malacol. Soc. London, 8: 198-201.

Tong PS, 2020. More policies and laws, is it better for biodiversity conservation in Malaysia? Conserv. Sci. Pract., 2: 1-11.

Turner RD and LN Santhakumaran, 1989. The genera Martesia and Lignopholas in the indo-pacific (Mollusca: Bivalvia: Pholadidae). Ophelia, 30: 155-186.

Way K and RD Purchon, 1981. The marine shelled Mollusca of west Malaysia and Singapore part 3, Bivalvia. J. Molluscan Stud., 47: 313-321.

Wong NLWS and A Arshad, 2011. A brief review on marine shelled mollusca (Gastropoda and Bivalvia) record in Malaysia. J. Fish. Aquat. Sci., 6: 669-699.

Zakirah MT, ML Shabdin, AR Khairul-Adha and M Fatimah-A'tirah, 2019. Distribution of intertidal flat macrobenthos in Buntal Bay, Sarawak, Borneo. Songklanakarin J. Sci. Technol., 41: 1048-1058.

Zieritz A, L Jainih, J Pfeiffer, KAA Rahim, H Prayogo, MS Anwari, AH Fikri, F Diba, H Taha, Z Sulaiman, E Froufe and M Lopes-Lima, 2021. A new genus and two new, rare freshwater mussel (Bivalvia: Unionidae) species endemic to Borneo are threatened by ongoing habitat destruction. Aquat. Conserv. Mar. Freshw. Ecosyst., 1-15.

Zieritz A and M Lopes-Lima, 2018. Handbook and national red-list of the freshwater mussels of Malaysia. IUCN, Kuala Lumpur.pp. 1-29.

Zieritz A, H Taha, M Lopes-Lima, J Pfeiffer, KW Sing, Z Sulaiman, S McGowan and KA Khairul, 2020. Towards the conservation of Borneo's freshwater mussels: rediscovery of the endemic Ctenodesma borneensis and first record of the non-native Sinanodonta lauta. Biodivers. Conserv., 29: 2235-2253. 